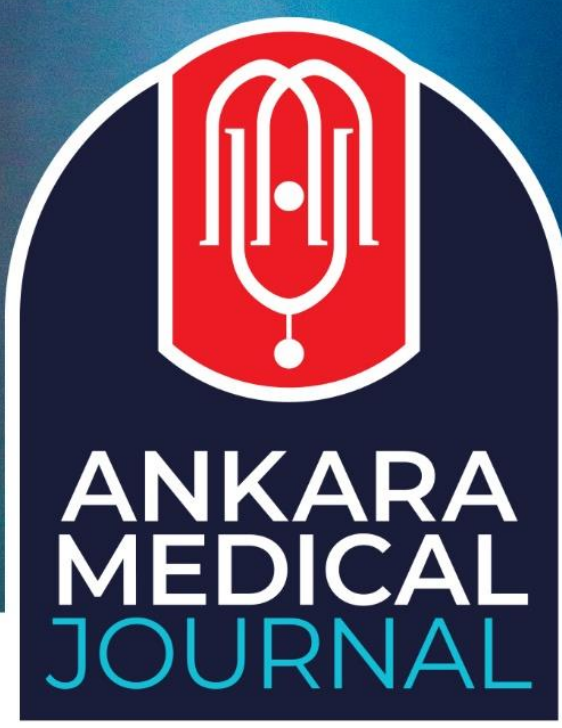

Research Article

Ankara Med J, 2021;(1):163-175 // 100 10.5505/amj.2021.34711

\title{
THE IMPACT OF GENDER AWARENESS TRAINING ON GENDER ROLE ATTITUDES OF WORKING WOMEN
}

\section{TOPLUMSAL CİNSIYYET FARKINDALIK EĞİTIMINIIN İŞÇİ KADINLARIN TOPLUMSAL CINSIYYTT ROL TUTUMLARINA ETKISİ}

(D) Ilknur Aydin Avci'1, (D) Özge Öz Yıldırım¹, (D) Dilek Çelik Eren'1

\section{(i) Senem Gurkan ${ }^{2}$}

${ }^{1}$ Ondokuz Mayıs University, Health Science Faculty, Public Health Nursing Department, Samsun ${ }^{2}$ Ondokuz Mayıs University, Social Sciences Institute, Women and Family Studies Department Samsun

Yazışma Adresi / Correspondence:

Özge ÖZ YILDIRIM (e-mail: ozge.oz@omu.edu.tr)

Geliş Tarihi (Submitted): 22.09.2020 // Kabul Tarihi (Accepted): 11.03.2021

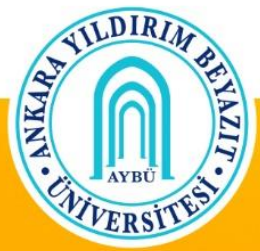

Ankara Yildırım Beyazıt University Faculty of Medicine Department of Family Medicine 


\title{
Öz
}

Amaç: Bu çalışma işçi kadınlara verilen toplumsal cinsiyet farkındalık eğitiminin, işçilerin toplumsal cinsiyet rollerine ilişkin tutumları üzerine etkisini değerlendirmek amacıyla yapılmıștır.

Materyal ve Metot: Bu araştırma yarı deneysel araştırma tasarımlarından tek grupta ön test son test deneme modeline göre yapılmıştır. Çalışmaya bir fabrikada çalışan, araştırmaya katılmaya gönüllü olan, girişimi tamamlayan 166 kadın işçi dahil edilmiştir. Çalışmada işçilere toplumsal cinsiyet farkındalığına iliş̧in 4 oturumdan oluşan 8 saatlik bir eğitim verilmiştir. Eğitim öncesi ön test olarak işçilere sosyo-demografik özelliklerini inceleyen soru formu ve toplumsal cinsiyet rolleri tutum ölçeği uygulanmıştır. Eğitiminin sonunda son test yapılarak toplumsal cinsiyet tutumu rolleri üzerindeki değişiklik belirlenmiştir. Verilerin değerlendirilmesinde tanımlayıcı istatistikler, Paired-t, independent-t ve ki-kare testi uygulanmıştır. Araştırmaya başlamadan önce etik kuruldan ve ilgili fabrika yönetiminden yazılı izin, araştırma kapsamındaki işçilerden sözel onam alınmıştır.

Bulgular: Eğitim durumu lise olan, orta ekonomik düzey sahip olan ve ilçede yaşayan işçiler kadın olma ile ilgili daha fazla sorun yaşamaktadırlar. İşçi kadınların Toplumsal cinsiyet rolleri tutum ölçeği toplam puanlarında eğitim sonrasında $(155,45 \pm 17,48)$ eğitim öncesine $(149,72 \pm 19,54)$ göre artış belirlenmiş, aralarındaki istatistiki olarak anlamlı bulunmuştur $(\mathrm{p}=0,006)$.

Sonuç: Bu çalışma ile işçi kadınlara toplumsal cinsiyet rolleri tutumlarını değiştirmek amacıyla verilen eğitim sonunda işçilerin toplumsal cinsiyet rolleri tutumları ölçeği toplam puanı, Kadın Cinsiyet Rolü ve Geleneksel Cinsiyet Rolü alt boyutlarında puan artışı meydana gelmiștir.

Anahtar Kelimeler: Toplumsal cinsiyet, toplumsal cinsiyet rolleri, eğitim programı.

\begin{abstract}
Objectives: This study was conducted in order to assess the impact of Gender Awareness Training on gender role attitudes of women workers.

Materials and Methods: The research was conducted with a pre-test - post-test model in a non-randomized single group with a quasi-experimental research design. The participants of the study were 166 female workers who work in a factory. During the research, the workers were given an 8-hour training on gender awareness in 4 sessions. Before the training, a questionnaire form investigating the socio-demographic characteristics of workers and the Gender Roles Attitude Scale (GRAS) were applied to the workers as a pretest. After training, the change in gender role attitudes was identified by means of post-test. Descriptive statistics, independent-t, and chi-square test, Anova, and Paired t-test were used for analyzing the data. Before starting the research, permission from the ethical committee and factory management was taken.

Results: The women whose education level was high school, whose economic condition was middle, and who lived in the district have more problems for being female. The total scores of the participants from the Gender Roles Attitude Scale have increased from $(155.45 \pm 17.48)$ to $(149.72 \pm 19.54)$ as before the training program and after the training $\operatorname{program}(\mathrm{p}=0.006)$.

Conclusion: At the end of the training, it was found out that there has been an increase in women's total gender role attitude scores, in the sub-dimensions such as female gender role attitude and traditional gender role attitude.
\end{abstract}

Keywords: Gender, gender role, training programs. 


\section{Introduction}

According to World Health Organization (WHO), gender is the social construction of the characteristics of women and men such as roles, norms, and relationships between groups of women and men. ${ }^{1}$ Emotions, attitudes, behaviors, and differences between roles that boys and girls learn, and that culture finds "suitable" for their gender in the process of socialization are gender differences. ${ }^{2}$ Gender inequality means any discrimination, deprivation, or restrictions based on gender which prevents or eliminates or intends to prevent or eliminate the recognition, use, and utilization of human rights and basic freedoms of women in political, economic, social, cultural, or business life. Gender equality causes numerous problems by affecting women's participation in education and business life or their income negatively and creating social pressure. ${ }^{3}$ Education and employment status are significant resources for empowering women. ${ }^{4}$ The difference between literacy and schooling of women and men is the most significant indicator of gender inequality. In the whole world, two-thirds of the 900 million illiterate people are women. ${ }^{5}$

The underlying causes of disadvantages that women, who constitute approximately half of the world's population, are involved in business life are mostly economic and cultural. The economic and social welfare and development of a country are in parallel with improving the employment status of women and increasing employment opportunities for them. In European Union member countries, the rate of women in business life is $53 \%$. In Turkey, the participation rate in labor is found as $70.4 \%$ for men and $29.3 \%$ for women. The barriers that women encounter in business life are mostly because of their gender. Problems regarding this matter can be listed in various aspects from not being able to get equal pay for equal work and social roles that women undertake as people who are deemed responsible for childcare and housework. ${ }^{6}$ In a study conducted with teachers, it was found that gender role attitudes of female teachers were better than male teachers; ${ }^{7}$ its was found that gender attitudes of women were high level in a different study conducted with married women. ${ }^{8}$ In a research carried out with university students, it was determined that students had equalitarian attitude in terms of gender roles in general, ${ }^{9}$ female students had more equalitarian gender perception than male students. ${ }^{10}$ In the study of Aydın et al. (2016), it was found that attitudes regarding gender roles were egalitarian. ${ }^{11}$

Participation in business life and employment in administrative positions are the areas where women are exposed to gender inequality the most. Barriers such as especially unequal pay for equal work, employment of women in lower numbers, not noting hierarchy in career promotion, preferring mostly men in administrative positions - glass ceiling syndrome, preferring mostly men in recruitment because of women's physiological needs during pregnancy, natal and postnatal periods, employing primarily male employees especially in the industrial sector are the outcome of gender inequality in business life. ${ }^{12-15}$ Disadvantageous positions of women in social life also affect their work life. It was reported that women living in rural areas 
have to work mostly as agricultural workers and they work in qualified jobs on a lower level.16,17 Furthermore, cultural prejudices and taboos do not consider jobs in which women would work with men, especially such as the industrial sector, suitable for women. ${ }^{18,19}$ This leads to gender-based inequality for women in business life.

According to "Gender Equality" which is the fifth sustainable development goal; it is aimed that gender equality is to be improved and women and girls are empowered on every level. ${ }^{20}$ While achieving sustainable development goals of the country, it is quite important that incentives and supports are offered for women who constitute half of the community to take an active part in business life. This would be an important step for ensuring the equality of women and men. Healthcare professionals working in the field of community health should aim to achieve sustainable development goals as they are involved in every field of the community. With the purpose of achieving this sustainable development goal in realizing occupational health activities, which is one of the fields of study of community health, studies should be carried out on women's awareness of their gender role attitudes. This study is conducted with the purpose of assessing the impact of social gender awareness training program given to working women on their attitudes regarding the gender roles of workers.

\section{Materials and Methods}

The research was conducted between April 2017 - May 2017 at a factory located in Amasya province, according to the pre-test - post-test model in a non-randomized single group with a quasi-experimental research design.

The factory where the study was conducted manufactures metal industrial products. Although most men work in this sector, there are also a limited number of female employees, especially in white-collar positions. The factory was built in a rural area and workers consisted of individuals who live in the area in general. In the area where the factory is located, women mostly work in the agriculture sector. The factory is located in an area where cultural barriers against women's working as blue-collar workers are seen extensively in general. One of the employees requested from the factory management that his wife is employed because of the financial difficulties that they face and the management allowed the women to work. The woman who started working was exposed to social pressure at the beginning, but the social pressure diminished in time after she had started working and her contribution to the family economy became visible. The working movement that a woman started in this way resulted in other women's job requests from the factory. At the time when the study was carried out, 200 female workers were working at the factory. 


\section{Population and Sample of the Research}

166 female worker participants who work in a factory, volunteered to participate in the research and completed all training modules. Before the research, announcements were made to each and every worker at the factory. The study was conducted with volunteers who responded to the call and wanted to participate in the program. In other words, sampling was not made and 166 women were included in the study as improbable.

\section{Data Collection Tools}

The data was collected by an introductory questionnaire consisting of 14 questions developed by researchers which investigate socio-demographic characteristics and the "Gender Roles Attitude Scale" consisting of 38 questions (Figure 1).

Gender Roles Attitude Scale (GRAS)

Developed by Zeyneloğlu and Terzioğlu in 2011, Gender Roles Attitude Scale (GRAS) contains 38 items and 5 dimensions in total ${ }^{21}$. Dimensions of the scale are egalitarian gender roles, female gender roles, marriage gender roles, traditional gender roles, and male gender roles. This 5-point Likert type scale is scored for equalitarian attitude sentences regarding gender roles as 5 points for 'completely agree,' 4 points for 'agree,' 3 points for 'undecided,' 2 points for 'disagree,' and 1 point for 'absolutely disagree'. According to this scoring scale, the highest score was calculated as '190' and the lowest score was calculated as '38'. The highest score obtained from the scale indicated that the students had 'egalitarian attitudes' towards gender roles and the lowest score showed that the students had 'traditional attitudes.' GRAS contains 38 items and five dimensions. 'Egalitarian gender roles', 'female gender roles', 'marriage gender roles' and 'traditional gender roles' dimensions of the scale contain eight items and the 'male gender roles' dimension of the scale contains six items. Egalitarian Gender Roles: Women and men share roles and responsibilities in daily life equally (items 5, 16, 21, 26, 33, 9, 14, and 24). Female Gender Roles: Roles and responsibilities assigned to woman by society (items 35, 37, 1, 25, 46, 23, 6, and 19). Cronbach's Alpha Reliability Coefficient of the scale was found to be "0.92" for 38 items. This indicates that items in the scale have high internal consistency and high reliability with each other. Cronbach's alpha coefficient of the scale in this research was found to be 0.88 .

\section{Data Collection}

In this research, workers were given an 8-hour training on social gender awareness in 4 sessions. Each session was held for 45-60 minutes and the whole education lasted for two days. The training was given by two researchers who had trainer's training in this field and who are in the research team. In the training, 
women were divided into two groups and each group was given the same training by the same trainers with the same content. The curriculum of the training contained topics of gender-related definitions, culture, social values, factors affecting awareness, and gender in business life. The training was given using audio-visual materials, educational videos with the question and answer method. The training aimed to raise social gender awareness by means of real-life stories of women.

Before the training, a questionnaire form investigating the sociodemographic characteristics of workers and a Gender Roles Attitude Scale were applied to the workers as a pre-test. At the end of the training, the change in gender role attitudes was identified by means of post-test.

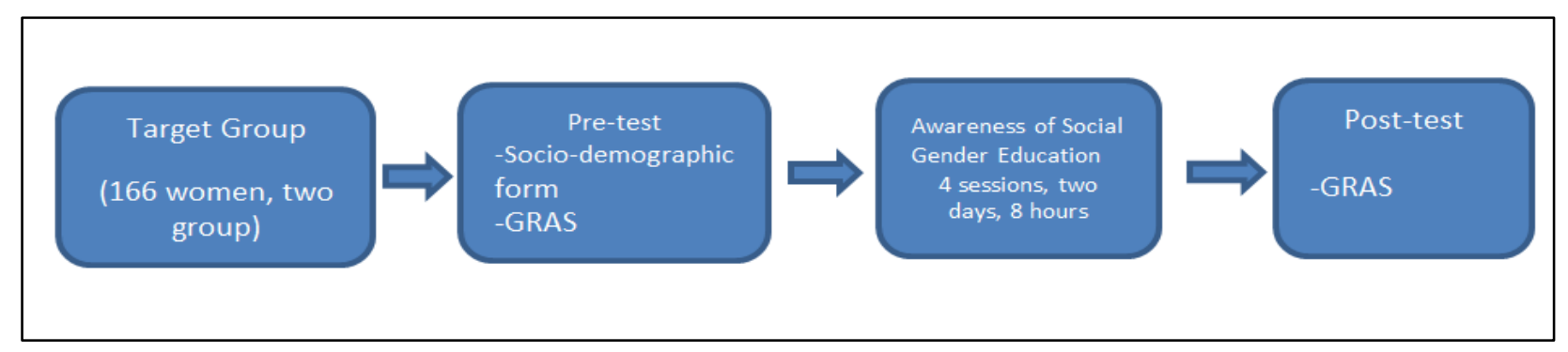

Figure 1. Flow chart

\section{Data Analysis}

The data obtained from the research was assessed on SPSS 21.0 Software on a computer. Descriptive statistics, independent- $t$, and chi-square test, Anova, and Paired t-test were used for analyzing the data.

\section{Limitations of the Research}

This study is limited to the women who work at the factory and agreed to participate in the research.

\section{Results}

$70.48 \%$ of the women in the research are married, $36.75 \%$ do not have children, husbands of $91.60 \%$ are employed and an education level of 33.13\% in high school. 81.93\% of the women stated their thoughts about their children's gender as does not matter girl or boy. 61.45\% experienced problems about being a woman and about their problems $30.39 \%$ of them said they are not able to go somewhere alone, $14.71 \%$ said they could not go to school because their families send boys to school and $13.73 \%$ said they have low wage and work without social security (Table 1). 
Within the scope of the study, the education level of $37.25 \%$ of the workers who have problems about being a woman was high school ( $\mathrm{p}=0.036)$, economic status of $81.37 \%$ was moderate $(\mathrm{p}=0.016), 91.18 \%$ were living in the district $(\mathrm{p}=0.05)$ and the relationship between them was found to be statistically significant (Table 2$)$.

At the end of the training given to the female workers within the scope of the research; it was determined that their gender roles attitude scale total score increased after training $(155.45 \pm 17.48)$ compared to before training $(149.72 \pm 19.54)(\mathrm{p}=0.006)$; female gender roles dimension score increased after training $(31.51 \pm 5.14)$ compared to before training $(28.58 \pm 5.64)(\mathrm{p}<0.001)$; traditional gender dimension score increased after training $(32.05 \pm 4.98)$ compared to before training $(29.75 \pm 5.87)(p<0.001)$ and the difference between them was found to be statistically significant (Figure 2).

Table 1. Socio-demographic characteristics of working women $(n=166)$

\begin{tabular}{|c|c|c|}
\hline \multirow[t]{2}{*}{ Age $($ mean \pm SD) } & \multicolumn{2}{|c|}{$\begin{array}{c}31.71 \pm 6.08 \\
\text { (min:19; max:52) }\end{array}$} \\
\hline & $\mathbf{n}$ & $\%$ \\
\hline \multicolumn{3}{|l|}{ Marital status } \\
\hline Married & 117 & 70.48 \\
\hline Single & 49 & 29.52 \\
\hline \multicolumn{3}{|l|}{ Children number } \\
\hline None & 61 & 36.75 \\
\hline 1 & 63 & 37.95 \\
\hline 2 & 9 & 5.43 \\
\hline 3 & 33 & 19.87 \\
\hline \multicolumn{3}{|l|}{ Working status of the husband } \\
\hline Yes & 109 & 91.60 \\
\hline No & 10 & 8.40 \\
\hline \multicolumn{3}{|l|}{ Education levels } \\
\hline Primary school & 41 & 24.70 \\
\hline Secondary school & 26 & 15.66 \\
\hline High school & 55 & 33.13 \\
\hline University & 44 & 26.51 \\
\hline \multicolumn{3}{|l|}{ Economic status } \\
\hline Good & 17 & 10.24 \\
\hline Middle & 127 & 76.51 \\
\hline Bad & 22 & 13.25 \\
\hline \multicolumn{3}{|l|}{ Thoughts about their children's gender } \\
\hline Girl & 20 & 12.05 \\
\hline Boy & 10 & 6.02 \\
\hline Does not matter (girl or boy) & 136 & 81.93 \\
\hline \multicolumn{3}{|c|}{ Facing problems because of being a woman } \\
\hline Yes & 102 & 61.45 \\
\hline No & 64 & 38.55 \\
\hline \multicolumn{3}{|l|}{ Experienced problems $*$} \\
\hline Not being able to go somewhere alone & 31 & 30.39 \\
\hline
\end{tabular}




\begin{tabular}{|l|c|c|}
\hline Not getting an education as the families only send boys to school & 15 & 14.71 \\
\hline Having low wage and working without social security & 14 & 13.73 \\
\hline Not having a right to the decisions in the family & 11 & 10.78 \\
\hline Marrying my family's decision & 9 & 8.82 \\
\hline Having responsibility for housework & 9 & 8.82 \\
\hline Having lack of own assets & 7 & 6.86 \\
\hline Being exposed to violence & 6 & 5.89 \\
\hline
\end{tabular}

There was a change in gender roles attitude scale; egalitarian gender role dimension score after training (32.92 \pm 7.11$)$ compared to before training $(33.33 \pm 7.07)(\mathrm{p}=0.599)$; marriage gender roles dimension score after training (32.56 \pm 3.66$)$ compared to before training $(32.50 \pm 4.05)(\mathrm{p}=0.879)$; male gender roles dimension score after training $(26.41 \pm 3.56)$ compared to before training $(25.57 \pm 4.19)(\mathrm{p}=0.058)$, but this difference was not found to be statistically significant (Figure 2).

Table 2. The Comparison of Women Workers' Facing with Some Problems Because of Being a Woman with some variables

\begin{tabular}{|c|c|c|c|c|c|}
\hline \multirow[t]{3}{*}{ Variables } & \multicolumn{5}{|c|}{ Have problems because of being a woman } \\
\hline & \multicolumn{2}{|c|}{ Yes } & \multicolumn{2}{|c|}{ No } & \\
\hline & $\mathbf{n}$ & $\%$ & $\mathbf{n}$ & $\%$ & \\
\hline \multicolumn{6}{|l|}{ Education level } \\
\hline Primary school & 27 & 26.47 & 14 & 21.88 & $p=0.036$ \\
\hline Secondary school & 18 & 17.65 & 8 & 12.50 & $\mathrm{X}^{2}=8.554$ \\
\hline High school & 38 & 37.25 & 17 & 26.56 & \\
\hline University & 19 & 18.63 & 25 & 39.06 & \\
\hline \multicolumn{6}{|l|}{ Marital status } \\
\hline Married & 76 & 74.51 & 41 & 64.06 & $\mathrm{p}=0.165$ \\
\hline Single & 26 & 25.49 & 23 & 35.94 & $\mathrm{X}^{2}=2.063$ \\
\hline \multicolumn{6}{|l|}{ Economic status } \\
\hline Good & 5 & 4.90 & 12 & 18.75 & $p=0.016$ \\
\hline Middle & 83 & 81.37 & 44 & 68.75 & $X^{2}=8.227$ \\
\hline Bad & 14 & 13.73 & 8 & 12.50 & \\
\hline \multicolumn{6}{|l|}{ Living place } \\
\hline Village & 3 & 2.94 & 7 & 10.94 & $X^{2}=5.974$ \\
\hline District & 93 & 91.18 & 56 & 87.50 & $p=0.05$ \\
\hline City & 6 & 5.88 & 1 & 1.56 & \\
\hline \multicolumn{6}{|c|}{ Working status of Husband } \\
\hline Yes & 72 & 93.51 & 37 & 88.10 & $\mathrm{p}=0.321$ \\
\hline No & 5 & 6.49 & 5 & 11.90 & $X^{2}=1.034$ \\
\hline
\end{tabular}




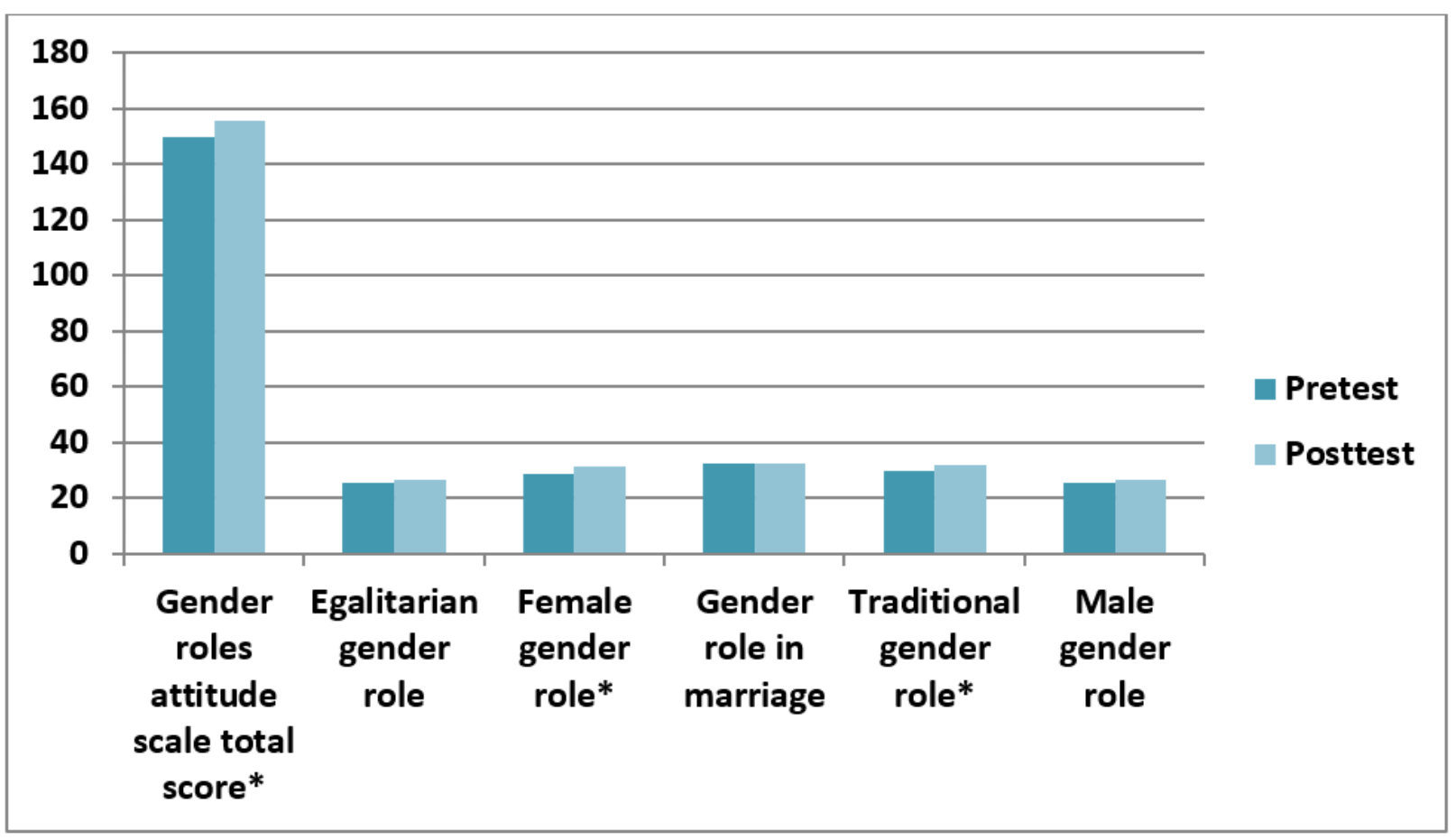

Figure 2. Evaluation of dimensions of Gender Roles Attitude Scale after training and before training for women

Gender roles attitude scale total scores of single female workers within the scope of the study before training $(155.29 \pm 21.40)$ were higher than married women $(147.39 \pm 18.30)$ and the difference was found to be statistically significant ( $\mathrm{p}=0.017$ ). No statistically significant difference was found between the gender roles attitude scale total scores of women after training and their marital status $(\mathrm{p}=0.785)$. It was determined that the gender roles attitude scale total scores of women whose education level is high school before training

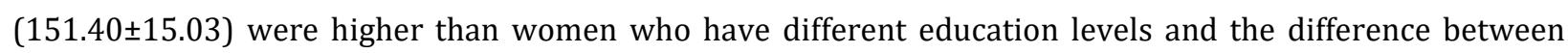
them was found to be statistically significant $(\mathrm{p}<0.001)$. No statistically significant difference was found between the gender roles attitude scale total scores of women after training and their education status $(\mathrm{p}=0.161)$ (Table 3).

Gender roles attitude scale total scores of women who know the definition of gender before training (156.57 \pm 22.23$)$ were higher than women who do not know the definition $(147.89 \pm 18.42)$ and the difference was found to be statistically significant $(p=0.019)$. No statistically significant difference was found between the gender roles attitude scale total scores of women after training and whether they know the definition of gender $(\mathrm{p}=0.541)$ (Table 3). 
Table.3 Comparing the total scores of Gender Roles Attitude Scale before and after education with some variables

\begin{tabular}{|c|c|c|}
\hline & $\begin{array}{l}\text { Gender roles attitude scale total } \\
\text { score increased before training }\end{array}$ & $\begin{array}{l}\text { Gender roles attitude scale total } \\
\text { score increased after training }\end{array}$ \\
\hline \multicolumn{3}{|l|}{ Marital status } \\
\hline Married & $147.39 \pm 18.30$ & $155.21 \pm 17.45$ \\
\hline Single & $155.29 \pm 21.40$ & $156.02 \pm 17.73$ \\
\hline Statistic & $\mathrm{t}=-2.408, \mathbf{p}=\mathbf{0 . 0 1 7}$ & $F=-0.273, p=0.785$ \\
\hline \multicolumn{3}{|l|}{ Education level } \\
\hline Primary school & $138.49 \pm 19.19$ & $151.17 \pm 19.46$ \\
\hline Secondary school & $148.38 \pm 16.67$ & $152.77 \pm 16.67$ \\
\hline High school & $151.40 \pm 15.03$ & $158.42 \pm 15.84$ \\
\hline University & $149.72 \pm 19.54$ & $157.30 \pm 17.52$ \\
\hline Statistic & $\mathrm{F}=9.085, \mathbf{p}<\mathbf{0 . 0 0 1}$ & $\mathrm{F}=1.738, \mathrm{p}=0.161$ \\
\hline \multicolumn{3}{|l|}{ Economic status } \\
\hline Good & $148.27 \pm 18.1$ & $155.36 \pm 18.7$ \\
\hline Middle & $149.65 \pm 20.31$ & $155.76 \pm 17.95$ \\
\hline Bad & $152.12 \pm 15.81$ & $153.18 \pm 12.27$ \\
\hline Statistic & $\mathrm{F}=0.187, \mathrm{p}=0.829$ & $\mathrm{~F}=0.163, \mathrm{p}=0.850$ \\
\hline \multicolumn{3}{|c|}{ Working status of Husband } \\
\hline Yes & $147.39 \pm 18.13$ & $154.81 \pm 17.51$ \\
\hline No & $145.7 \pm 21.22$ & $163.2 \pm 16.16$ \\
\hline Statistic & $\mathrm{t}=0.279, \mathrm{p}=0.78$ & $\mathrm{t}=-1.459, \mathrm{p}=0.15$ \\
\hline \multicolumn{3}{|l|}{ Living place } \\
\hline Village & $155.30 \pm 17.35$ & $154.10 \pm 12.1$ \\
\hline District & $149.33 \pm 19.54$ & $156.18 \pm 17.7$ \\
\hline City & $150.14 \pm 23.99$ & $141.72 \pm 15.9$ \\
\hline Statistic & $\mathrm{F}=0.436, \mathrm{p}=0.647$ & $\mathrm{~F}=2.359, \mathrm{p}=0.098$ \\
\hline \multicolumn{3}{|c|}{ Know the definition of gender } \\
\hline Yes & $156.57 \pm 22.23$ & $157.06 \pm 16.47$ \\
\hline No & $147.89 \pm 18.42$ & $155.02 \pm 17.78$ \\
\hline Statistic & $\mathrm{t}=2.367, \mathbf{p}=\mathbf{0 . 0 1 9}$ & $\mathrm{t}=0.438, \mathrm{p}=0.541$ \\
\hline
\end{tabular}

\section{Discussion}

In this study, it was determined that gender role attitudes of women increased as a result of the social gender awareness training given to female workers working at a factory.

Before the training, the gender role attitudes of single women were better than those of married women; however, there was no difference between the attitudes of married and single women after the training. In a study that investigated marital status and gender role attitudes retrospectively, individuals who have been married for 20 years, single and divorced were investigated and it was found that gender role attitudes of single individuals changed for the better. ${ }^{22}$ In another study investigating the marital status and gender role 
attitudes, it was found that gender role attitudes of married healthcare professionals were higher than single healthcare professionals. ${ }^{23}$ According to the findings obtained from this study, perspectives of single individuals and married individuals regarding gender role attitudes differ. It might be thought that they have to attend to domestic works and be present at business life, and their gender role attitudes might change with responsibilities they undertake. After the training, gender role attitudes of both married and single women are equalized and there was no difference between them anymore. This indicates that the training given to the women is effective training.

Before the social gender awareness training given within the scope of the study, gender role attitudes of women whose education level is a high school were better than women with other education levels. After the training, there was no difference between gender role attitudes according to education status. In their study, Kaya and Uysal (2015) found that gender role attitudes get higher when the education level increases ${ }^{24}$. In other studies, which investigate education levels, it was determined that gender role attitudes increase as the education levels increase. ${ }^{10,25,26}$ As the education level increases, critical thinking skills and egalitarian perspectives of women might change in a positive direction. Therefore, it can be said that the findings of this study are an expected result. In addition, it is seen that the training program provided a positive impact on women with all education levels at the same rate, therefore there was no difference between education level and gender role attitude at the end of the training.

Moreover, gender role attitudes of women who had known the definition of gender were better than women who had not known the definition of gender before the training program, there was no difference between those women after the training. In the study of Özden and Gölbaşı carried out with healthcare professionals, they determined that healthcare professionals who have knowledge of the concept of gender had higher gender role attitudes. ${ }^{23}$ We can say that all women had equal knowledge at the end of the training.

While gender role attitudes of women increased positively as their age decrease before the training program given in this study, there was no relationship between age and attitude after the training. In the study of Seyitoğlu et al., it was determined that the young age group had egalitarian role attitudes compared to the older age group. ${ }^{27}$ In the study of Özden and Gölbaşı (2018), it was determined that gender role attitudes increased as the age increased. ${ }^{23}$ The fact that women's gender role attitudes increase as the age decreases suggest that traditional structure turns into a more modern structure and therefore younger women have more libertarian and egalitarian thought together with modernization. There was no difference between age and gender role attitudes after the training program, which suggests that the training program created positive impacts in every age group and such training programs should be generalized. 
Women who have high school education levels experience more problems about being a woman compared to women on other education levels. As the education level increases, the social awareness of the women might increase. It can be thought that they are aware of the roles and responsibilities that society assigned to them about being a woman and they are affected more by that.

Women who live in the district experience more problems about being a woman compared to women living in other residential areas. As districts are smaller residential areas compared to provinces, women living there can feel the social pressure of being a woman more clearly. In addition, as job opportunities are more limited in districts, this might cause that women compete against men and they are disadvantageous against men. It can be said that the findings gained from this research are an expected conclusion.

As a result of the training program given to female workers for the purpose of changing their gender role attitudes, it was found out that there has been an increase in women's total gender role attitude scores, the sub-dimensions such as female gender role attitude and traditional gender role attitude. Gender roles are the way of expressing their genders in social environments for women and men and this expression might differ among communities and thus cause inequality between genders. To prevent inequality, it can be suggested that more training programs should be given to raise social gender awareness. It will be beneficial that studies are conducted in line with the Sustainable Development Goals of the United Nations especially in communities where women face important barriers in business life.

\section{Ethical considerations}

The research was conducted by permission of the Social Sciences Ethical Committee of Ondokuz Mayis University (Number:2020/382) and factory management. Verbal consent was taken from workers who participated in the research.

\section{Conflict of interest}

The authors declare no conflict of interest. 


\section{References}

1. WHO. Gender, Equity and Human Rights. [Internet] http://www.who.int/gender-equityrights/understanding/gender-definition/en/.(Access date: 20.01.2020).

2. Dökmen ZY. Toplumsal cinsiyet, sosyal psikolojik açlklamalar. İstanbul: Remzi Kitapevi, 2016.

3. CEDAW. Concluding Comments: Turkey. Advance Unedited Version. 2005. [Internet] https://www.unicef.org/turkey/pdf/_gi18.pdf. (Access date:20.01.2020).

4. Hacettepe University Institute of Population Studies. Turkey Demographic and Health Survey .2013. [Internet] http://www.hips.hacettepe.edu.tr/tnsa2013/rapor/TNSA_2013_ana_rapor.pdf. (Access date: 20.01.2020).

5. Çalık KY, Erkaya R. Sağlığı koruma ve geliştirme ile toplumsal cinsiyetin ilişkisi. Demirbağ BC,Ed, Sağlı̆̆ı Koruma ve Geliştirme. Göktuğ Yayıncılık,2017;99-121.

6. Erci B, Kılıç D, Adıbelli D. Yaşam Boyu Sağlığı Geliştirme. Anadolu Nobel Tıp Kitapevleri,2018.

7. Ekşi H, Güneş F, Yaman N. The Investigation of Marital Adjustment of Teachers in terms of Psychological Well-being and Gender Roles. Turkish Psychological Counseling and Guidance Journal 2018; 8(50):203-33.

8. Yüksel Ö, Dağ İ. The Relationship Between Marital Adjustment and Psychological Symptoms in Women: The Mediator Roles of Coping Strategies and Gender Role Attitudes. Turkish Journal of Psychiatry 2015;26(3):181-8.

9. Karasu F, Göllüce A, Güvenç E, Çelik, S. The Attitudes of the University Students' Regarding the Gender Roles. Suleyman Demirel University Journal of Health Sciences 2017; 8(1): 21-7.

10. Esen E, Soylu Y, Siyez DM, Demirgürz G. Examination of Gender Perception of University Students According to Sex and Sex Roles. E-International Journal of Educational Research 2017;8(1):46-63, (doi: 10.19160/5000197327).

11. Aydın M, Bekar EÖ, Gören ŞY, Sungur MA. Attitudes of Nursing Students Regarding to Gender Roles. AIBU Journal of Social Sciences 2016;16(1):223-42.

12. Soysal A. Characteristics of Women Entrepreneurs, Prob- lems They Encountered and Suggestions to Women for Establishing Business: A Research in Kahramanmaras. Eskişehir Osmangazi University Journal of Economics and Administrative Sciences 2010;5(1):71-95.

13. Gül H, Yalçınoğlu N, Atlı ZC. The Status and Problems of Women in Working Life in Turkey. TAF Preventive Medicine Bulletin 2014: 13(2).

14. Küçük M. Women In Business Life and Problems Encountered: A Research Relevant to Laborer Women Employed Under an Employer. Ekonomi Bilimleri Dergisi 2015; 7(1):1-17.

15. Özçelik MK. Women's Place And Career Development Barriers In Working Life. ASOS Journal 2017;5(52):49-70. 
16. Candan E, Günal SÖ. Women's Labor In Agriculture. Turkish Journal of Agricultural Economics 2013:19(1).

17. Şahinli MA, Şahbaz N. Women Employment Profile At Agriculture Sector In Turkey. International Journal of Social and Economic Sciences 2013;3(1):55-70.

18. Özçatal EÖ. Patriarchy, gender and women's participation in working life. Çankırı Karatekin University Journal of the Faculty of Economics and Administrative Sciences 2011;1(1):21-39.

19. Karaduman CG, Ergun A. Women Managers' Experiences and Strategies in Male Dominated Business Environment. Journal of Sociological Research 2018;21(2):114-43.

20. United nations development programme. Human Development Report. 2016 [Internet] http://hdr.undp.org/sites/default/files/2016_human_development_report.pdf. (Access date: 20.01.2020).

21. Zeyneloğlu S, Füsun T. Development And Psychometric Properties Gender Roles attitude Scale. H. U. Journal of Education 2011;40: 409-20.

22. Lucier-Greer M, Adler-Baeder F. An Examination of Gender Role Attitude Change Patterns Among Continuously Married, Divorced, and Remarried Individuals, Journal of Divorce \& Remarriage 2011;52(4): 225-43 (doi: 10.1080/10502556.2011.556977).

23. Özden S, Gölbaşı Z. Determination of Health Workers' Attitudes Towards Gender Roles. Journal of Health Sciences of Kocaeli University 2018;4(3):95-100.

24. Kaya FŞ, Uysal V. A Research About Social Gender Roles And Religiosity Perceptions in Society. Journal of International Social Research 2015; 8(36):646-62

25. Altuntaş O, Altınova HH. Determining The Relationship Between Gender Perception and Socioeconomic Variables. Turkish Studies-International Periodical for the Languages, Literature and History of Turkish or Turkic 2015; 10(6):83-100.

26. Çetinkaya KS. The Examınation Of The Relationship Between Tendency Of Violence And Gender Roles Attitudes Among The University Students. Nesne Journal of Psychology 2013;1 (2):21-43.

27. Seyitoğlu DC, Güneş G, Gökçe A. Determining the Attitudes of the Students of inönü university, faculty of medicine, on social gender roles. Medicine Science 2016;5(1):102-16. 